\title{
ONLINE GAME QUIZ "KAHOOT" IN TEACHING ENGLISH FOR STUDENTS OF SMP MUHAMMADIYAH YOGYAKARTA
}

\author{
Annafi Annanda Oktaria ${ }^{1}$, Laksmita Rohmayadevi², Didik Murwantono ${ }^{3}$ \\ 1,2,3 Ahmad Dahlan University \\ ${ }^{1}$ anna.nafi.okta@gmail.com, ${ }^{2}$ laksmitamita7@gmail.com, ${ }^{3}$ didik_025@yahoo.com
}

\begin{abstract}
Gamification is gaining momentum together with technology-infused training as an advancement to inspire and engage students in their learning process. The correlation between game play and increased motivation and interaction is shown by strong evidence. More and more games of learning appear, offering a promise to help learning a language. This research was designed in descriptive qualitative research; data was collected by short questions to be answered on the application of Kahoot online application in English classrooms. The aim in this research to analyze motivation of the students and to enrich the dynamics of the lessons introducing Kahoot in the English classroom in order to achieve improve the tasks related to vocabulary, aimed at defining vocabulary. The research design was qualitative research concerning phenomenological studies with a sample of 30 students of Junior High School of SMP Muhammadiyah Yogyakarta. It used an open-ended questionnaire to collect the data of the students' perceptions. Data analysis of the questionnaires was analyzed qualitatively by interview. With the media Kahoot can improve student learning achievement as evidence that the results of learning English experience a significant increase in value. It is very helpful for students in addition to understanding English subject matter.
\end{abstract}

Keywords: Education, Kahoot, Learning, Motivation, Smartphone

\section{INTRODUCTION}

Technology is a major part of students' lives, and their academic training requires an introduction to the uses of technolog (Susanti, 2017). Technology in the classroom can vary from low-tech pencil, paper, and chalkboard to the use of presentation technology, and hightech computers, electronic networking and conference devices, and much more. The latest technology allows us to test things that were previously impossible in physical and virtual classrooms. What can be used basically depends on what the educators do.

Nowadays, the majority of schools have get admission to to science that gives teaching and studying excessive quality, excessive capability and ultra-fast net access. Connected school rooms nowadays make information, instructing and training resources, peers, specialists and the wider neighborhood simpler, handy and easy. It allows instructors to instruct the usage of applications, such as Youtube or retaining on-line conversations with Skype or Google Hangouts. For the games, teachers can use Edpuzzle, Memrise, Socrative or Kahoot. These application can be useful for teaching English.

Prieto et al. (2019) note that the benefits gained from the use of new technologies will depend on the extent to which they are used in ways compatible with the learning process. Utilizing Kahoot helps support student metacognition by providing immediate feedback. Kahoot also offers the opportunity to not only assess students' conceptual understandings but also support the construction of new knowledge and understanding through further explanation during or 
after the game. This study will find out the use of Kahoot to change students' motivation in learning English.

Game-based activities have always been interesting and enjoy for language teaching and learning. Technology of education, gamification is innovation to motivate and to engage students in their learning process. In the present, the educational system still uses a traditional framework for teaching. But, now many people use everything is digital, with download $t$ and quick updates use of an app, becoming a loyal customer or engaging in sport activities. In recent years, a new trend called gamification has evolved as an approach to engage and encourage active participation (Tóth et al., 2019). (Bista et al., 2012) By definition, gamification is the use of game elements in a non-game context. It is important to separate play, which is a free form of action, and games to entertain from serious games that usually encompass real-world activities.

Stojkovi \& Jeroti (2011) referred to that there are many blessings of the use of games in the classroom; games are a welcome ruin from the standard events of the language class, they are motivating and challenging, getting to know a language requires an excellent deal of effort and it helps college students to make and maintain the effort of learning, video games supply language practice in the various skills, they encourage college students to have interaction and communicate, and they create a meaningful context for language use.

To increase their motivation, language learners need to change. Games are one thing for motivation to increase. The teacher, however, must take into account the need, complexity and age of the students when developing language games for the language school. Players can be used for all ages so teachers need not be too easy or difficult for the students to ensure that their players follow age expectations.

Our aim was mainly to motivate the students and to enrich the dynamics of the lessons introducing Kahoot in the English classroom in order to achieve through competition positive learning, implying that learners can involve more actively in the English classroom, the researcher thought that, being short questions to be answered in a short time, we would only enhance learning by memory. We hoped that students would improve the tasks related to vocabulary, aimed at defining vocabulary.

\section{Kahoot}

Kahoot is an online game that assessments student understands of route content. The recreation is free for each teachers and students, and actually requires a multimedia tool to take part (Pede, 2017). A cellphone, laptop, or Chromebook works for strolling the Kahoot website. Teachers can create quizzes the usage of more than one desire questions introduced in a game-based structure to students.

According to (Al-hadithy \& Ali, 2018), Kahoot is an online learning game that can grow students' intrinsic motivation. He revealed that there was a marked increase in active learning, student involvement, self-efficacy, independent learning and an increase in the results of summative assessment after integrating Kahoot.

The Kahoot contain questions that have up to four possible choices, and questions can incorporate more than a few multimedia contents such as images or movies (Basuki \& Hidayati, 2019). Kahoot has been well recommended for large-size class, in which student-student and student-teacher interactivity are difficult to stimulate. Having been utilized in a variety of subjects, from science to social studies, Kahoot has also exerted positive impact in language teaching and learning. Several literature reviews claimed its benefits and positive effects on 
student learning, such as providing immediate feedback, increasing participation in class, and improving retention of the focal material (Mustangin, 2019)

Kahoot is used as game-based school room response machine performed by using the total classification in real time. As an assessment based totally tool, Kahoot supports assessments, productive formative assessments and pupil reflection. To start, instructors register for a free account through going to https://create. kahoot.it. Once registered, educators can pick out from hundreds of thousands of free public games and adapt them as necessary, or create their own. The process is convenient and straightforward.

\section{Motivation}

The definition of motivation is the force that energizes and directs a behavior towards a goal (Mustangin, 2019). In Education, motivation deals with the problem of setting up conditions so that learners will perform to the best of their abilities in academic settings. We often motivate learners by helping them develop an expectancy that a benefit will occur as a result of their participation in an instructional experience.

The concept of motivation is linked closely to other constructs of attention, needs, goals and interests which are all contribute to stimulating students' interest in learning and their intention to engage in particular activities and achieve various goals. Krashen as cited from Richards and Rodger, 2001:183 argues that "learners with high motivation generally do better, and learners with self-confidence and a good self-image tend to be more successful". It is related to using games in teaching English to increase the students' motivation. This opinion is supported by Chen (2007) as cited by (Mustangin, 2019) that games are workable because they can easily attract the attention of students, thus influencing students' motivation and enhancing English ability.

Saville-Troike (2006:85-86) as referred to through (Lennartsson, 2008) claims that character motivation is every other aspect that is used to provide an explanation for why some L2 freshmen are greater successful than others. The more motivated students are, the simpler they will learn a new language. (Wallraven, Kaulard, Kürner, \& Pepperell, 2008) cited (Prieto et al., 2019) as stated by means of Williams states that students' motivation is a crucial factor that is quintessential for great education. How we recognize the students are encouraged is when they pay attention, begin working on venture immediately, ask question and volunteer answer, and appear to be blissful and eager.

(Susanti, 2017) Fun Activities in Teaching English by Using Kahoot. This research found Kahoot can be used to monitor each student's knowledge and to identify areas where the students would benefit from more one-to-one teaching, but it is more generally used as a break from traditional classroom activities. (Prieto et al., 2019) The effects of the online game Kahoot on science vocabulary acquisition. The Research observed that all students accelerated their vocabulary assessment ratings when Kahoot was once played twice weekly. The use of Kahoot also improved pupil focal point and on venture behavior. The results of the pupil pride survey indicated that students enjoyed enjoying Kahoot and observed it handy to use.

The similarities between Susi Susanti's research and this research are the method used is qualitative study and the topic of discussion is about Kahoot. The difference is the subject of the previous research was from universities and this research from Junior High School. The similarities between Joseph Pede's research and this lookup are the approach used is qualitative learn about and the subject matter of dialogue is about Kahoot. The difference is the fabric used in Kahoot, this research used science vocabulary. 


\title{
METHOD
}

The researchers utilized a qualitative research method concerning a phenomenological study to address the three research questions. A phenomenological study is designed to describe and interpret experience by determining the meaning of it as perceived by the people who have participated it. This research involved 30 students Junior High School of SMP Muhammadiyah Yogyakarta and one English teacher. At first, the teacher was given twice training with the aid of Kahoot's online application. Then the students that consisted of 20 female and 10 male students implemented Kahoot their daily online quiz three times of each platform, within one week. The web app online Kahoot were done in the multimedia laboratory, so there was not any issue concerning the internet connections. The teacher was involved in teaching English courses in the ELT class because they must practice teaching using Kahoot. The researchers collected the data of the students' perceptions of the Kahoot efficacy in their daily online quiz using questionnaries. The questionnaires were divided into two for students and teacher. The questionnaries for students is to have a depiction of the students' perceptions and to analyze the students motivation. While the questionnaries for teacher is to analyze the teachers perceptions of Kahoot. The data analysis measures use 30 students'experiences open-ended questions. Finally, the reseachers concluded to find the results.

Table 1 Questionaries for students

\begin{tabular}{|c|}
\hline Question for Students Learning Kahoot \\
\hline $\begin{array}{l}\text { When you join Kahoot quiz, can you answer question in Kahoot correctly? } \\
\text { Why? }\end{array}$ \\
\hline Can you apply the material explained before to answer Kahoot quiz? \\
\hline $\begin{array}{l}\text { How is your feeling when you do quiz in Kahoot? Do you feel happy or worry } \\
\text { or lazy? }\end{array}$ \\
\hline What is your opinion about Kahoot quiz? \\
\hline What are advantages that you can get after join Kahoot quiz? \\
\hline
\end{tabular}

Table 2 Questionaries for Teachers

\author{
Question for Teachers Learning Kahoot
}

Do you know Kahoot before get the training?

Can you make quiz using Kahoot?

Do you think Kahoot is good for teaching English? Give your reasons

What is your opinion about Kahoot quiz? 


\section{What are advantages that you can get from Kahoot quiz?}

\section{RESULTS AND DISCUSSION}

\section{Results}

The results of this study are that Kahoot has many advantages such as free learning platformbased games, as educational technology. By playing Kahoot this learning becomes very fun and makes students not bored following learning which is very difficult to understand. Using Kahoot aims as a formative assessment for teachers, it can help teachers monitor each student's progress towards learning goals, identify strengths and weaknesses, and to identify areas where students will benefit from more than one teaching, more challenging learning opportunities, or reviews of basic knowledge for the subject. More experienced users also integrate Kahoot into their curriculum to introduce new topics, improve retention of new facts, revise before exams, challenge classes around the world, opinion surveys, gather insights, facilitate discussion, or to reward and restore learners' energy in the study.

In these lines, from the students' view as the result of this research, there is some students' preference for Kahoot. First, Kahoot is more interesting, motivating and fun. Second, Kahoot is more addictive. Third, Kahoot makes students more confident/positive. Fourth, Kahoot makes students more eager to grasp the lessons in the classroom or autonomous learning at home. Fifth, Kahoot creates a more energetic classroom atmosphere. Sixth, Kahoot allows students to finish the quiz more independently. Seventh, Kahoot makes students more focus on doing the quiz. Eight, Kahoot results from a fairer and objective score. Ninth, Kahoot is more familiar and simpler (no need more body movements). Lastly, the tenth, Kahoot questions' feedbacks (memes) are entertaining.

\section{Discussion}

The need for Kahoot in the students' daily online Kahoot was one point on which they do really agree. However, the present research once also has proven that Kahoot are engaging, addicting and motivating the students to learn and achieve more. In line with it, motivated learners tend to show a favorable attitude toward the subject, engage and interest to shows favorable attitude and will to exert the goal of learning. In addition, the teacher designs learning activities that can make students in active learner mode. In this case, the teachers are challenged to involve students actively during teaching and learning activities using Kahoot. To use Kahoot as a powerful tool during teaching and learning activities, preparation is one of the main ways to make it more meaningful before applying several other ways to encourage students to become active learners.

This finding is related to that can be applied when using media in English classrooms, such as Kahoot. (Kuranchie-Mensah \& Amponsah-Tawiah, 2016) state that higher education institutions have begun to use learning technology, to present lecture content in new ways, to encourage students to participate in classes anonymously and to give them more meaningful revision methods. Furthermore, the use of Kahoot can help the effectiveness of learning in English classroom. Based on the previous research the use of Kahoot is very effective and helps the learning process in English classroom. 
According to Bicen (2018) cited in (Prieto et al., 2019) Kahoot application can be used effectively for gamification lessons. By applying gamification using this media can have an influence on college students which makes them extra formidable and prompted to learn. Using Kahoot online media in the getting to know method can enrich the first-class of student studying in the classroom, with the very best influences reporting on type dynamics, involvement, and motivation and enhancing getting to know experiences. In relation to these findings, it has to be committed to them, to be better than before to get an appreciation of the material directions or assignments given by way of the teacher. So, it can be extra tremendous through the usage of Kahoot in English lecture room learning.

However there is still one possible weakness of the popularity of Kahoot. It is the concern that students will begin to be bored of playing the game (Wang, 2015). His study found that the online game played everyday had no effect on the classroom dynamics, student engagement, or student motivation. In fact, his study showed participants like to continue to play Kahoot after every lecture and they thought that they learned something from playing Kahoot (Wang, 2015).

\section{CONCLUSION}

The strategy using Kahoot online based application media can increase students learning motivation evidence that the results of learning English can experience a significant increase. With the media Kahoot can improve student learning achievement as evidence that the results of learning English experience a significant increase in value. It is very helpful for students in addition to understanding English subject matter. Based on the results of these studies there are findings of research related to learning English with Kahoot online based application strategy as an effort to increase student motivation and learning achievement. There are several suggestions that need to be conveyed, namely to implement Kahoot as a learning media that requires proper preparation, so that teachers implement teaching and learning activities are able and truly master the material to be delivered to students.

Then the teachers' role is very important in the continuity of student teaching and learning activities, therefore it is not enough just to teach the material taught, but also the teacher can provide or insert lessons that are character or affective in nature, so as to influence students in increasing motivation. Furthermore, for teachers to always develop their personal cognitive abilities, in order to improve the personal quality of the teacher, so that teaching the teacher easily teaches or implements strategies using Kahoot to support student achievement improvement especially English subjects and in general other subject matter. Then, there is a need for continuous follow up; because follow up can provide knowledge on the extent of good quality and achievement results and can find out the mistakes that need to be addressed.

\section{ACKNOWLEDGMENTS}

We thank our informants who made this study complete. We hope this study would be essential for the readers and become a useful reference for the next research.

\section{REFERENCES}

Al-hadithy, T., \& Ali, S. (2018). Gamification in Learning English for Academic Purposes : Designing Assessment for Learning Using. 5, 66-70.

Basuki, Y., \& Hidayati, Y. (2019). Kahoot! or Quizizz: the Students' Perspectives. 
https://doi.org/10.4108/eai.27-4-2019.2285331

Bista, S. K., Nepal, S., Colineau, N., \& Paris, C. (2012). Using gamification in an online community. CollaborateCom 2012 - Proceedings of the 8th International Conference on Collaborative Computing: Networking, Applications and Worksharing, October, 611618. https://doi.org/10.4108/icst.collaboratecom.2012.250526

Kuranchie-Mensah, E. B., \& Amponsah-Tawiah, K. (2016). Employee motivation and work performance: A comparative study of mining companies in Ghana. Journal of Industrial Engineering and Management, 9(2), 255-309. https://doi.org/10.3926/jiem.1530

Lennartsson, F. (2008). Students' motivation and attitudes towards learning a second language -. English, August.

Mustangin, M. (2019). Improve Student Engagement and Collaboration with Kahoot! Jurnal Teknologi Dan Bisnis, 1(1), 59-65. https://doi.org/10.37087/jtb.v1i1.6

Pede, J. (2017). The effects of the online game Kahoot on science vocabulary acquisition Part of the Science and Mathematics Education Commons, and the Special Education and Teaching Commons. 5-11. http://rdw.rowan.edu/etdhttp://rdw.rowan.edu/etd/2405

Prieto, M. C., Palma, L. O., Tobías, P. J. B., \& León, F. J. M. (2019). Student assessment of the use of kahoot in the learning process of science and mathematics. Education Sciences, 9(1). https://doi.org/10.3390/educsci9010055

Stojkovi, M. K., \& Jeroti, D. M. (2011). Reasons for Using or Avoiding Games in an EFL Classroom. 1st International Conference on Foreign Language Teaching and Applied Linguistics, 940-947. https://pdfs.semanticscholar.org/e85c/bdab02cf32014ef9aa02fa1e0a27b956a587.pdf

Susanti, S. (2017). Fun Activities in Teaching Enlish by Using Kahoot! 2nd International Seminar on Education 2017 Empowering Local Wisdom on Education for Global Issue, 453-458.

Tóth, Á., Lógó, P., \& Lógó, E. (2019). The effect of the kahoot quiz on the student's results in the exam. Periodica Polytechnica Social and Management Sciences, 27(2), 173-179. https://doi.org/10.3311/PPso.12464

Wang, A. I. (2015). The wear out effect of a game-based student response system. Computers and Education, 82, 217-227. https://doi.org/10.1016/j.compedu.2014.11.004 